\title{
АДМІНІСТРАТИВНІ ДЕЛІКТИ В ПОДАТКОВІЙ СФЕРІ
}

Прохоров К. О.

Стаття присвячена аналізу сутності адміністративних деліктів у податковій сфері. Автором з'ясовано, що адміністративна відповідальність за податкові правопорушення виконує особливі завдання, а саме: 1) упорядкування суспільних відносин у податковій сфері, припинення й виправлення неналежної поведінки суб'єктів у вказаній сфері; 2) охорона чинного конституційного ладу та публічного порядку, забезпечення законності й захист інтересів держави та суспільства; 3) покарання винного в учиненні адміністративного правопорушення в податковій сфері та запобігання аналогічним правопорушенням цим суб'єктом. Автором визначено, що адміністративна відповідальність за податкові правопорушення здійснює певні функції, які окреслюють вихідні напрями впливу на суспільні відносини в податковій сфері та сфері господарювання.

Ключові слова: податкові відносини, податкові делікти, адміністративна відповідальність, завдання адміністративної відповідальності, функції адміністративної відповідальності.

Статья посвящена анализу сущности административных деликтов в налоговой сфере. Автором установлено, что административная ответственность за налоговые правонарушения выполняет особые задачи, а именно: 1) упорядочение общественных отношений в налоговой сфере, прекращение и исправление ненадлежащего пове дения субъектов в указанной сфере; 2) охрана существующего конституционного строя и общественного порядка, обеспечение законности и защита интересов государства и общества; 3) наказание виновного в совершении административного правонарушения в налоговой сфере и предупреждение аналогичных правонарушений этим субъектом. Автором определено, что административная ответственность за налоговые правонарушения имеет определенные функции, которые определяют выходные направления воздействия на общественные отношения в налоговой сфере и сфере хозяйствования.

Ключевые слова: налоговые отношения, налоговые деликты, административная ответственность, задачи административной ответственности, функции административной ответственности.

The article is devoted to the analysis of the essence of administrative tort in the tax sphere. The author found that administrative responsibility for tax offenses performs special tasks, in particular: 1) streamlining public relations in the tax sphere and terminating and correcting the inappropriate behavior of entities in this field; 2) the protection of the existing constitutional system and public order, the rule of law and the protection of the interests of the state and society; 3 ) the punishment of the perpetrator of an administrative offense in the tax sphere and the prevention of similar offenses by this entity.

The author determines that administrative responsibility for tax offenses carries out certain functions that determine the output directions of impact on public relations in the tax and business sectors.

The author finds out that administrative responsibility, as a separate type of legal responsibility, is an integral element of the legal compliance system in the tax sphere. The article substantiates that an administrative offense under
Art. 164-1 of the Code of Ukraine on administrative offenses, characterized by a specific manifestation (form, order, legal consequences). The analysis carried out signs of administrative responsibility for tax offenses. Signs of a general level make it possible to understand administrative responsibility for tax offenses as an organic part of the legal compliance system in the tax sphere. Signs of a special level make an understanding of this responsibility, occurs as a result of an offense covered by the system of administrative offenses in the tax sphere. The author highlights the features of a special level as a separate practical manifestation of the corresponding industry responsibility arising in the indicated sphere of legal relations.

Key words: tax relations, tax tort, administrative responsibility, tasks of administrative responsibility, functions of administrative responsibility.

Постановка проблеми та її актуальність. Удосконалення системи податкових відносин в Україні зумовлює важливість зміцнення механізму юридичної відповідальності за податкові делікти. На жаль, механізм адміністративної відповідальності за податкові правопорушення має численні вади, існування яких негативно відображується як на рівні корупції в державі, так і на наповненні державного та місцевих бюджетів. У поєднанні з недостатнім висвітленням проблематики, пов'язаної з учиненням податкових деліктів, на теоретико-методологічному рівні вказане зумовлює актуальність і своєчасність теми статті.

Аналіз останніх досліджень і публікацій. Тією чи іншою мірою адміністративна відповідальність у податковій сфері загалом і в контексті порушення ст. 164-1 Кодексу України про адміністративні правопорушення (далі - КУпАП) зокрема вже досліджувалася українськими вченими (наприклад, О.І. Баїк, О.М. Бандуркою, О.О. Долгим, В.В. Іщенком, Ю.В. Марочкіною, В.Д. Понікаровим, С.М. Поповою та ін.). Поряд із тим, не применшуючи вже опублікованих результатів дослідження проблематики адміністративної відповідальності за податкові правопорушення, варто констатувати, що сучасна юридична думка стосовно вказаної відповідальності потребує систематизації та актуалізації.

Отже, метою статті $\epsilon$ узагальнене викладення юридичної особливості адміністративної відповідальності за податкові правопорушення з урахуванням контекстуальної юридичної природи відповідальності, передбаченої ст. 164-1 КУПАП.

Виклад основного матеріалу. В КУпАП натепер міститься низка норм, які передбачають адміністративну відповідальність за податкові правопорушення, зокрема ст. 164-1, що встановлює відповідальність за порушення порядку подання декларації про доходи та ведення обліку доходів і витрат. Тобто особливим для правопорушення, передбаченого у ст. 164-1 КУпАП, $\epsilon$ те, що воно, будучи складником загальної системи 
податкових правопорушень, у цій системі знаходиться в підсистемі особливої групи протиправних діянь, які також уважаються у світлі норм КУпАП водночас й адміністративними правопорушеннями в податковій сфері (фінансовій чи господарській сферах загалом).

При цьому більш повно відповідальність за порушення ст. 164-1 КУпАП як за податкове правопорушення, за яке настає адміністративна відповідальність, може бути науково осмислена в результаті виокремлення та систематизації особливих рис адміністративної відповідальності за податкові правопорушення, у контексті чого будуть з'ясовуватися особливі риси відповідальності за порушення ст. 164-1 КУпАП. Отже, аналізуючи норми чинного законодавства, а також підходи вчених до розуміння юридичної природи адміністративної відповідальності за податкові правопорушення [7; 8, с. 86-95; 9; 10], можемо дійти висновку, що до основних ознак адміністративної відповідальності за податкові правопорушення варто зарахувати такі характерні риси цього виду юридичної відповідальності:

1. Адміністративна відповідальність за податкові правопорушення настає на підставі й у порядку, закріпленому в нормах адміністративного законодавства, з урахуванням норм податкового, господарського законодавства. Варто мати на увазі, що в ст. 7 КУпАП закріплено правило стосовно забезпечення законності під час застосування заходів впливу за адміністративні правопорушення, відповідно до якого «ніхто не може бути підданий заходу впливу в зв'язку з адміністративним правопорушенням інакше як на підставах і в порядку, встановлених законом». Певна річ, у КУпАП не можуть бути детально окреслені вичерпні дані про сутність об'єкта правопорушення у сфері податків і фінансів загалом, що суперечило б принципу нормотворчої економії. 3 огляду на це, в КУпАП викладено лише необхідний обсяг складів адміністративного правопорушення, а вичерпна інформація про юридичну сутність об'єкта та суб'єкта відповідних правопорушень міститься (має міститися) у спеціальному законодавстві. У цьому сенсі адміністративна відповідальність за порушення порядку подання декларації про доходи та ведення обліку доходів і витрат застосовується на підставі ст. 164-1 КУпАП з урахуванням п. 49.18 ст. 49, п. 177.10 ст. 177 і підп. 296.1.1 п. 296.1 ст. 296 Податкового кодексу (далі - ПК) України, п. 6 ст. 128 Господарського кодексу України.

2. Адміністративна відповідальність за податкові правопорушення настає на підставі особливої фактичної підстави - податкового правопорушення, сутність якого визначається в п. $109.1 \mathrm{~cm} .109$ ПК України у взаємозв'язку з ч. $1 \mathrm{~cm}$. 9 КУпАП і конкретизується конкретною нормою КУпАП, у якій міститься склад відповідного правопорушення. Розглядувана відповідальність за правопорушення в податковій сфері $\epsilon$ відповідальністю за податкові правопорушення, які нормативним чином інтерпретується в адміністративно-правовій площині, тобто в межах засад теорії адміністративного правопорушення. Це означає, зокрема, те, що порушення тих чи інших порядків (наприклад, порядку подання декларації про доходи, порядку ведення обліку доходів і витрат), передбачених у чинних нормах податкового та/або господарського законодавства України, зумовлюють адміністративну відповідальність лише в тому разі, коли конструкція цих правопорушень буде відповідати типовій моделі складу адміністративного проступку.

3. Адміністративна відповідальність за податкові правопорушення переслідує особливу мету. Зважаючи на мету юридичної відповідальності загалом, можемо дійти висновку, що розглядувана відповідальність (також і в контексті ст. 164-1 КУпАП) сукупно спрямована на застосування до порушника норм адміністративного законодавства про податкові правопорушення, щоб: 1) регулювати й охороняти відносини у податковій сфері адміністративно-правовими інструментами впливу, щоб усунути наявну суспільну шкоду, мінімізувати ризики для чинного правопорядку, а також загрози для рівня національної (зокрема фінансової) безпеки держави, що зумовлюються податковим правопорушенням, за яке передбачається адміністративна відповідальність; 2) реалізувати принцип невідворотності юридичної відповідальності за адміністративні правопорушення в податковій сфері шляхом притягнення порушника відповідних положень КУпАП до адміністративної відповідальності за наявності для цього всіх підстав та умов; 3) підвищити рівень правосвідомості населення, віри в правопорядок, що зумовлюється демонстрацією всьому суспільству реальності настання відповідальності за адміністративні правопорушення в податковій сфері.

4. Адміністративна відповідальність за податкові правопорушення виконує особливі завдання, а саме: 1) упорядкування суспільних відносин у податковій сфері та припинення й виправлення неналежної поведінки суб'єктів у вказаній сфері (підвищує рівень законності, дисциплінованості, соціальної відповідальності тощо); 2) охорона чинного конституційного ладу й публічного порядку, забезпечення законності й захист інтересів держави та суспільства («публічного інтересу») стосовно належного перебігу суспільних відносин у податковій сфері; 3) покарання винного в учиненні адміністративного правопорушення в податковій сфері тазапобіганняаналогічнимправопорушеннямцимсуб' єктом (потенційними правопорушниками) у майбутньому.

5. Адміністративна відповідальність за податкові правопорушення здійснює певні функції, які окреслюють вихідні напрями впливу на суспільні відносини в податковій сфері та сфері господарювання. Зокрема, С.М. Попова вважає, що відповідальність за порушення податкового законодавства об'єднує два різні складники юридичної відповідальності: 1) правовідновну (компенсаційну), що «полягає в необхідності відшкодування державі платниками податків та/або їх посадовими особами збитків, що виникли внаслідок недоотримання надходжень бюджетами всіх рівнів від податків і зборів»; 2) штрафну (каральну), яка в рамках адміністративної відповідальності визначається положеннями КУпАП [11, с. 180].

Висновки. Адміністративна відповідальність як окремий вид юридичної відповідальності $\epsilon$ складником т. зв. «системи юридичної відповідності в податковій сфері», що настає в результаті порушення податкового (й у відповідній частині митного, господарського) законодавства. У контексті правопорушення, передбаченого ст. 164-1 КУпАП, можемо помітити, що досліджувана відповідальність характеризується не лише загальним, особливим, а й специфічним виявом (форма, порядок, юридичні наслідки), обумовленим санкцією зазначеної статті (при цьому вона застосо- 


\section{Правове забезпечення адміністративної реформи}

вується з урахуванням інших норм Загальної частини цього Кодексу). Це достатньою мірою підтверджує також аналіз ознак адміністративної відповідальності за податкові правопорушення, котрі в загальному вигляді можуть виокремлюватися та систематизуватися за рівнем міри їх диференціації: 1) ознаки загального рівня дають змогу розуміти адміністративну відповідальність за податкові правопорушення як органічної частини т. зв. «системи юридичної відповідності в податковій сфері»; 2) ознаки спеціального рівня уможливлюють розуміння вказаної відповідальності як відповідальності, що настає в результаті вчинення правопорушення, охопленого системою адміністративних правопорушень у податковій сфері; 3) ознаки особливого рівня дають змогу виокремлювати адміністративну відповідальність за правопорушення, передбачене ст. 164-1 КУпАП, як окремий практичний вияв відповідної галузевої відповідальності, що виникає в означеній сфері правових відносин.

\section{Література}

1. Тимченко А.М. Деякі особливості державного примусу при реалізації податкових правовідносин. Форум права. 2011. № 1. С. 1031-1037.

2. Гоцуляк Є.М. Склад та кваліфікуючі ознаки порушень податкового законодавства, за які передбачена адміністративна відповідальність. Юридичний науковий електронний журнал. 2014. № 6. С. 100-105.

3. Огороднікова І.І. Класифікація адміністративних правопорушень у сфері оподаткування. Вісник Запорізького національного університету. Серія «Юридичні науки». 2010. № 4. С. 155-162.

4. Роздайбіда А.В. Проблема систематизації і класифікації податкових правопорушень. Проблеми пра- вознавства та правоохоронної діяльності. 2002. № 1. C. 93-103.

5. Угровецький О.П. Система оподаткування в Україні: становлення, реформування, адміністрування. Харків : Золота миля, 2009. 328 с.

6. Іщенко В.В. Класифікація адміністративних правопорушень у сфері оподаткування: доктринальні підходи. Порівняльно-аналітичне право. 2017. № 1. С. 142-145.

7. Долгий 0.0. Облік адміністративних правопорушень як інформаційна умова забезпечення законності у сфері податкової діяльності суб'єктів господарювання в Україні. Науковий вісник Національного університету державної податкової служби України. 2013. № 4 (63). С. 32-38.

8. Марочкіна Ю.В. Адміністративна відповідальність за ухилення від сплати податків : дис. ... канд. юрид. наук : 12.00.07. Херсон, 2012. 198 с.

9. Сухоребра Т.І. Окремі питання адміністративної відповідальності за порушення у сфері оподаткування. Правничий вісник Університету КРОК. 2013. № 16. C. $166-169$.

10. Ярмоленко Ю.В. Адміністративна відповідальності за порушення вимог фінансового законодавства. Наше право. 2014. № 2. С. 162-168.

11. Попова С.М. Розширення адміністративної відповідальності за податкові правопорушення. Адміністративне право України: сучасний стан та шляхи розвитку : матер. наук.-практ. конф. (Харків, 27 квіт. 2012 р.). Харків : ХНУВС, 2012. С. 179-182.

Прохоров К. О., аспірант кафедри адміністративного, фінансового і банківського права Навчально-наукового інституту права імені князя Володимира Великого Міжрегіональної академії управління персоналом 